\title{
Development of gluten-free cakes with the addition of methylcellulose and xanthan gum
}

\section{Desenvolvimento de bolos sem glúten com adição de goma xantana e metilcelulose}

\author{
Viviane Borges Vallejos ${ }^{1 *}$; Tainara de Moraes Crizel $^{2}$; \\ Myriam de las Mercedes Salas-Mellado 3
}

\begin{abstract}
The removal of gluten results in many baking problems and many gluten-free products currently available in the market are of low quality. The addition of hydrocolloids, however, is an option to improve technological characteristics. The objective of this study was to evaluate the influence of the addition of methylcellulose and xanthan gum on the technological characteristics of gluten-free cakes made with $100 \%$ rice flour. Cakes using hydrocolloids at different concentrations were developed through an experimental design that evaluated technological features such as specific volume, crumb hardness and overall quality score. Mathematical models were obtained to describe the hardness and the score of cakes as a function of the addition of xanthan and methylcellulose. The smallest value of crumb hardness of the cakes was obtained when concentrations of $0.4 \%$ xanthan and $2 \%$ methylcellulose were added. With regards to the score, the highest value was obtained with the lowest levels of hydrocolloids, whose formulation contained $0.2 \%$ xanthan gum and $1 \%$ methylcellulose. It can be concluded that the addition of xanthan gum and methylcellulose enabled the development of a gluten-free cake with a softer crumb that presents technological quality attributes similar to that of a wheat cake.
\end{abstract}

Key words: Rice flour, hydrocolloids

\section{Resumo}

\begin{abstract}
A remoção do glúten resulta em problemas para a panificação e muitos dos produtos sem glúten disponíveis no mercado são de baixa qualidade, contudo a adição de hidrocolóides é uma opção para melhorar suas características tecnológicas. Este trabalho teve como objetivo avaliar a influência da adição de metilcelulose e goma xantana nas características tecnológicas de bolos sem glúten elaborados com $100 \%$ de farinha de arroz. Foram elaborados bolos utilizando hidrocolóides em diferentes concentrações através de planejamento experimental, sendo avaliadas características tecnológicas como volume específico, dureza do miolo e pontuação total. Foram obtidos modelos matemáticos para descrever a dureza e a pontuação dos bolos, em função da adição de xantana e metilcelulose. O menor valor de dureza do miolo dos bolos foi obtido quando adicionadas as concentrações de $0,4 \%$ de xantana e $2 \%$ de metilcelulose. Em relação a pontuação, o maior valor foi obtido com os menores teores dos hidrocolóides, cuja formulação continha $0,2 \%$ de goma xantana e $1 \%$ de metilcelulose. Pode-se concluir que a adição de goma xantana e metilcelulose proporcionou o desenvolvimento de um bolo sem glúten com miolo mais macio e apresentando atributos de qualidade tecnológica semelhantes a um bolo de trigo.
\end{abstract}

Palavras-chave: Farinha de arroz, hidrocolóides

\footnotetext{
1 Discente de Doutorado em Engenharia e Ciência de Alimentos, Universidade Federal de Rio Grande, FURG, Rio Grande, RS, Brasil. E-mail: viviane vallejos@hotmail.com

2 Discente de Doutorado em Ciência e Tecnologia de Alimentos, Universidade Federal do Rio Grande do Sul, UFRGS, Porto Alegre, RS, Brasil. E-mail: tainara_mc@hotmail.com

3 Prof ${ }^{a}$, Escola de Química e Alimentos, Universidade Federal de Rio Grande, FURG, Rio Grande, RS, Brasil. E-mail: mysame@ yahoo.com

* Author for correspondence
} 


\section{Introduction}

Bakery products are produced mainly from wheat flour. In the food industry, there is a constant search for raw materials that do not contain gluten and can result in products that have good acceptance by consumers, especially those with celiac disease (STORCK et al., 2009).

Celiac disease (CD) is an autoimmune disease that is triggered in genetically predisposed individuals due to a permanent intolerance to gluten (RODRIGO, 2006). The toxic fraction of gluten is gliadin, and this is responsible for the clinical manifestations of the disease (MOREIRA, 2007). The only effective treatment for celiac disease is a strict adherence to a gluten-free diet throughout the patient's life, which results in clinical and intestinal mucosa recovery (FIGUEIRA, 2010).

Rice and maize are the main cereals that are considered safe for celiacs, with rice being the most suitable for the production of gluten-free products due to its mild flavor and white color and the high digestibility of carbohydrates and hypoallergenicity of its proteins (NEUMANN; BRUEMMER, 1997).

The removal of gluten results in baking problems, and currently, many gluten-free products available in the market are of low quality because gluten is responsible for the extension and elasticity of the dough and the retention of air which gives volume to the products (ARENDT et al., 2002; PREICHARDT et al., 2009).

Among bakery products, cake has been gaining increasing importance in relation to consumption and marketing in Brazil. Many companies that already produce breads, cookies and toasts have entered the cake market in order to diversify their product line, allowing changes in industries that have moved from small to large scale (MOSCATTO et al., 2004; PAVANELLI et al., 2000).

Rice flour is an option for the replacement of wheat flour in bakery products, but rice proteins do not have a similar capacity to form a gluten network.
This makes it necessary to use hydrocolloids, such as methylcellulose (MC) and xanthan gum, which give greater stability to the products (NISHITA et al., 1976; ONYANGO et al., 2009; ROSELL; COLLAR, 2007). Cellulose derivatives (methylcellulose, carboxymethylcellulose and hydroxypropylmethylcellulose) are obtained by chemical modification of cellulose. This ensures their uniform properties in contrast to hydrocolloids of natural sources that have a high variability (GUARDA et al., 2004).

Methylcellulose has the ability to form gels in aqueous medium, is soluble in cold water and forms a barrier coating during heating which leads to reduction of water and oil loss (XUE; NGADI, 2009). It is used as an emulsifying, thickening, stabilizing, gelling, and suspending agent in food products, including bakery products, such as ice cream, salad dressings and mixed sauces (ASH, ASH, 1995; FCC, 1996).

Xanthan gum is a polysaccharide hydrocolloid that has excellent rheological properties of interest for use in food. It assists in gas retention and increases the specific volume of bakery products, and due to these characteristics, xanthan gum is being studied by many researchers (COLLAR et al., 1999; GUARDA et al., 2004; LAZARIDOU et al., 2007; TURABI et al., 2008).

This study aimed to evaluate the influence of the addition of methylcellulose and xanthan gum on the technological characteristics of gluten-free cakes.

\section{Material and Methods}

\section{Materials}

To obtain the cakes, rice flour provided by Cerealle Indústria e Comércio de Cereais Ltda., located in the city of Pelotas, Brazil, was used. The additives added were Methocel hydrocolloid methylcellulose $\mathrm{A}_{4} \mathrm{M}^{\circledR}$ and $\mathrm{Keltrol}^{\circledR}$ xanthan gum, provided by Tovani Benzaquen and CPKelco companies, respectively. The other ingredients, 
sugar, baking powder (baking soda), milk, eggs, margarine and salt (sodium chloride), were purchased in local shops.

\section{Chemical composition of rice flour}

Ash content (oven at $550-600^{\circ} \mathrm{C}$ ), humidity (oven at $105{ }^{\circ} \mathrm{C}$ ), lipids (Soxhlet method) and proteins (Kjeldahl method) were evaluated according to the official methods of the AACC (2000). Carbohydrates were calculated by difference.

\section{Experimental design}

The analysis of the combined effect of individual variables on the technological characteristics of the cake was conducted using a full factorial experimental design type of central composite rotational design, which involved two independent variables: the addition of xanthan gum and the addition of methylcellulose. Table 1 shows the actual levels of coded independent variables and comprises the lower points $(-1)$, upper points $(+1)$, center $(0)$ and axial points $(+\alpha$ and $-\alpha)$. The actual levels were selected after conducting preliminary tests.

The matrix of the experimental design used is presented in Table 2. Eleven trials were performed: four factorial (combinations of levels -1 and +1 ), four axial $(-\alpha$ and $+\alpha)$ and three replicates at the center point (0).

Table 1. Variables and levels of full $2^{2}$ rotational central composite design for gluten-free cakes.

\begin{tabular}{lccccc}
\hline \multirow{2}{*}{\multicolumn{1}{c}{ Independent variable }} & $-\alpha$ & -1 & 0 & +1 & $+\alpha$ \\
\cline { 2 - 5 } & 0.12 & 0.2 & 0.4 & 0.6 & 0.68 \\
\hline Xanthan gum (\%) $*$ & 0.6 & 1 & 2 & 3 & 3.4 \\
Methylcellulose (\%) * & & &
\end{tabular}

* Rice flour based percentages. $-\alpha=-1.41 \mathrm{e}+\alpha=+1.41$.

Table 2. Matrix of full rotational central composite design $2^{2}$.

\begin{tabular}{ccccc}
\hline \multirow{2}{*}{ Essay } & \multicolumn{2}{c}{ Xanthan gum } & \multicolumn{2}{c}{ Methylcellulose } \\
\cline { 2 - 5 } & Coded & Real $(\%) *$ & Coded & Real (\%) * \\
\hline 1 & -1 & 0.2 & -1 & 1 \\
2 & +1 & 0.6 & -1 & 1 \\
3 & -1 & 0.2 & +1 & 3 \\
4 & +1 & 0.6 & +1 & 2 \\
5 & $-\alpha$ & 0.12 & 0 & 2 \\
6 & $+\alpha$ & 0.68 & 0 & 0.6 \\
7 & 0 & 0.4 & $-\mathrm{a}$ & 3.4 \\
8 & 0 & 0.4 & $+\mathrm{a}$ & 2 \\
9 & 0 & 0.4 & 0 & 2 \\
10 & 0 & 0.4 & 0 & 2 \\
11 & 0 & 0.4 & 0 & \\
\hline
\end{tabular}

\footnotetext{
* Rice flour based percentages. $-\alpha=-1.41 \mathrm{e}+\alpha=+1.41$.
} 


\section{Preparation of cakes}

For the cake preparation, the formulation presented in Table 3 was used. Cakes were prepared according to Borges et al. (2006) with adaptations. Firstly, the egg, sugar and margarine were placed in a mixer ("Stand Mixer" 300 Watts, BEA30A model) and mixed for 3 minutes at high speed. Then, flour, salt, methylcellulose, xanthan and milk were added, mixing for 3 minutes at medium speed. Lastly, the yeast was added, and the dough was homogenized for 1 minute at medium speed. A total of $175 \mathrm{~g}$ of dough was placed in each aluminum shape $(15.5 \mathrm{x}$ $7.4 \mathrm{~cm}$ and a height of $4.5 \mathrm{~cm})$, previously greased with margarine and rice flour, and then placed in the electric oven (Fischer, Diplomat 09:01:09 Model), preheated for 15 minutes and baked for 20 minutes at $200{ }^{\circ} \mathrm{C}$. The cakes were removed from the oven after baking and cooled to room temperature for an hour, after which the analyses were carried out.

Table 3. Formulation of gluten-free cakes.

\begin{tabular}{cc}
\hline Ingredients & Amount $(\mathrm{g})$ \\
\hline Rice flour & 100 \\
Margarine & 32 \\
Crystal sugar & 62 \\
Whole milk & 62 \\
Egg & 40 \\
Baking powder & 3.7 \\
Salt & 1 \\
Xanthan gum & $0.12 \%-0.68 \% *$ \\
Methylcellulose & $0.6 \%-3.4 \%^{*}$ \\
\hline
\end{tabular}

* Rice flour based percentages according to the experimental design.

\section{Evaluation of cakes}

The specific volume $\left(\mathrm{mL} \cdot \mathrm{g}^{-1}\right)$ of the cakes was obtained by the ratio between the apparent volume $(\mathrm{mL})$ and the cake mass (g) after baking. The mass was obtained by weighing the cakes on a precision scale (Marte, model AS200). The apparent volume of the cakes was determined by the method of displacement of millet seeds (PIZZINATO; CAMPAGNOLLI, 1993).

The attributes of the technological quality of the cakes were evaluated according to Neitzel (2006) by use of a spreadsheet consisting of an adaptation of the AACC method 10-90 (2000), shown in Table 4. The cakes were evaluated by trained judges according to the most relevant aspects of crumb quality: structure (uniformity, alveolar size and wall thickness); grain (surface roughness of the crumb); texture (moisture, smoothness and cohesiveness); color; and flavor (smell/taste). The sum of the scores assigns a total score for each cake.

To determine the hardness of the cake crumb, an analysis was performed on a texture analyzer (Stable Micro System, Model TA.XTplus) using the software Exponent according to method number 74-09 of the AACC (2000). This consists of placing two central $25 \mathrm{~mm}$ thick slices on the platform center of the texture analyzer and compression with a cylindrical $36 \mathrm{~mm}$ diameter probe to $40 \%$ of its original height. The test conditions were as follows: pre-test speed $1.0 \mathrm{~mm} \cdot \mathrm{sec}^{-1}$, test speed of $1.7 \mathrm{~mm} \cdot \mathrm{sec}^{-1}$ and post-test speed of $10 \mathrm{~mm} \cdot \mathrm{sec}^{-1}$. 
Table 4. Evaluation worksheet of the technological score (NEITZEL, 2006).

\begin{tabular}{|c|c|c|c|}
\hline \multicolumn{4}{|c|}{ TECHNOLOGICAL SCORE } \\
\hline \multirow{10}{*}{ a. Structure } & \multirow{3}{*}{ 1. Uniformity } & Uniform (normal) & 10 \\
\hline & & Slightly disuniform & 6 \\
\hline & & Disuniform & 2 \\
\hline & \multirow{4}{*}{ 2. Alveolar Size } & Compact(normal) & 10 \\
\hline & & Closed & 8 \\
\hline & & Slightly open & 6 \\
\hline & & Open & 4 \\
\hline & \multirow{3}{*}{ 3. Wall Thickness } & Thin & 10 \\
\hline & & Slightly Thick & 6 \\
\hline & & Thick & 2 \\
\hline \multirow{3}{*}{ b. Grain } & & Silky & 16 \\
\hline & & Rough & 10 \\
\hline & & Coarse & 8 \\
\hline \multirow{11}{*}{ c. Texture } & \multirow{4}{*}{ 1. Moisture } & Moist (normal) & 10 \\
\hline & & Slightly dry & 8 \\
\hline & & Gummy & 6 \\
\hline & & Dry & 4 \\
\hline & \multirow{4}{*}{ 2. Smoothness } & Very smooth(normal) & 14 \\
\hline & & Smooth & 12 \\
\hline & & Slightly Hard & 10 \\
\hline & & Hard & 4 \\
\hline & \multirow{3}{*}{ 3. Cohesiveness } & Tender & 10 \\
\hline & & Slightly firm & 8 \\
\hline & & Firm & 4 \\
\hline \multirow{4}{*}{ d. Crumb color } & & Brilliant cream & 10 \\
\hline & & Slightly opaque or white & 8 \\
\hline & & White & 6 \\
\hline & & Slightly opaque and white & 4 \\
\hline \multirow{3}{*}{ e. Flavor } & & Normal & 10 \\
\hline & & Strange & 0 \\
\hline & SUM & & \\
\hline
\end{tabular}

\section{Statistical analysis}

The results of the experimental design were analyzed statistically using response surface methodology (BOX; DRAPER, 1987).

\section{Results and Discussion}

Chemical composition of the raw material

The results for the chemical composition of the rice flour on a dry basis was $7.52 \%$ protein, $0.41 \%$ fat, $0.31 \%$ ash, and $91.76 \%$ carbohydrates. The rice flour had $8.93 \%$ moisture. These data indicate that it has low moisture content. Ronda and Ross (2011) used rice flour containing $15.1 \%$ moisture in the preparation of gluten-free breads. 
The protein content is in agreement with expectations. In a study by Storck et al. (2009), breads were developed using gluten-free rice flour with $7.3 \%$ protein, a value close to that found in this work. However, Turabi et al. (2008) used rice flour with $10 \%$ moisture, $6 \%$ protein and $0.6 \%$ ash in the preparation of gluten-free cakes with different hydrocolloids, and this flour showed high moisture content and low protein content.
Evaluation of the technological characteristics of the cakes

Table 5 shows the values of the specific volume of gluten-free cakes. The cakes, weighing approximately $155 \mathrm{~g}$, presented a specific volume between 1.71 and $2.10 \mathrm{~cm}^{3} \cdot \mathrm{g}^{-1}$.

Table 5. Influence of addition of xanthan gum and methylcellulose on the technological characteristics of the glutenfree rice flour based cakes.

\begin{tabular}{cccccc}
\hline Essay & $\begin{array}{c}\text { Xanthan gum } \\
(\%)^{*}\end{array}$ & $\begin{array}{c}\text { Methylcellulose } \\
(\%)^{*}\end{array}$ & SV $(\mathrm{mL} / \mathrm{g})$ & Hardness $(\mathrm{g})$ & Score \\
\hline 1 & 0.2 & 1 & $1.75 \pm 0.01$ & $1088.58 \pm 44.43$ & $90.00 \pm 0.00$ \\
2 & 0.6 & 1 & $1.71 \pm 0.02$ & $1147.71 \pm 247.18$ & $80.33 \pm 1.15$ \\
3 & 0.2 & 3 & $1.82 \pm 0.02$ & $1207.76 \pm 68.57$ & $77.00 \pm 3.46$ \\
4 & 0.6 & 3 & $1.78 \pm 0.02$ & $1222.54 \pm 122.66$ & $73.00 \pm 0.00$ \\
5 & 0.12 & 2 & $2.05 \pm 0.02$ & $935.17 \pm 54.68$ & $83.00 \pm 1.12$ \\
6 & 0.68 & 2 & $2.03 \pm 0.05$ & $1186.80 \pm 47.11$ & $72.33 \pm 0.00$ \\
7 & 0.4 & 0.6 & $2.10 \pm 0.04$ & $1149.09 \pm 22.79$ & $85.33 \pm 1.00$ \\
8 & 0.4 & 3.4 & $1.99 \pm 0.05$ & $1171.06 \pm 31.41$ & $73.00 \pm 1.15$ \\
9 & 0.4 & 2 & $2.01 \pm 0.03$ & $827.332 \pm 56.10$ & $77.00 \pm 1.00$ \\
10 & 0.4 & 2 & $1.89 \pm 0.02$ & $802.36 \pm 40.58$ & $78.66 \pm 0.58$ \\
11 & 0.4 & 2 & $1.91 \pm 0.03$ & $885.53 \pm 76.33$ & $79.34 \pm 4.04$ \\
\hline
\end{tabular}

* Rice flour based percentages. SV= Specific volume.

The results obtained were similar to those found by Gorgônio et al. (2011) and better than those reported by Turabi et al. (2008). Gorgônio et al. (2011) gave values of 1.89 and $1.94 \mathrm{~cm}^{3} \cdot \mathrm{g}^{-1}$ for the specific volume of sugar-free cakes, fiber-based and gluten-free from mixed pumpkin seed and corn starch flour. Turabi et al. (2008) reported a specific volume of $1.51 \mathrm{~cm}^{3} \cdot \mathrm{g}^{-1}$ for the addition of $1 \%$ xanthan gum and $1.20 \mathrm{~cm}^{3} \cdot \mathrm{g}^{-1}$ for the addition of $1 \%$ hydroxypropylmethylcellulose (HPMC) in glutenfree cakes prepared separately with rice flour. This difference in the values of specific volume may have occurred because the concentrations of xanthan gum added were not the same. It is also believed that the addition of xanthan gum concurrently with the addition of methylcellulose has a positive influence on the specific volume of gluten-free cake due to the change in viscosity of the dough, which causes a greater retention of the gas formed during fermentation.

It was found that neither of the independent variables (addition of xanthan or addition of methylcellulose) showed a significant effect ( $p$ $<0.10$ ) on the volume of the cakes. Under the conditions studied, it was not possible to establish a mathematical model for the volume of the cakes.

It is observed in Table 5 that the values of crumb hardness of the cakes ranged from 802.36 to $1222.54 \mathrm{~g}$. These values were similar to those of some of the cakes evaluated by Turabi et al. (2008), which were between approximately 700 and $3500 \mathrm{~g}$, for gluten-free cakes from rice flour with different hydrocolloids and emulsifiers added. 
The rice cakes from rice flour with xanthan gum and methylcellulose added showed low values of hardness and consequently, a softer crumb, which is a desirable feature for this product.

For hardness values, it was possible to verify a significant effect $(\mathrm{p}<0.10)$ of the variables, allowing the establishment of a mathematical model under the conditions studied, according to equation (1):

$$
\begin{gathered}
\mathrm{y}=838.1912+53.7484 \mathrm{x}_{1}+125.7668\left(\mathrm{x}_{1}\right)^{2} \\
+175.6084\left(\mathrm{x}_{2}\right)^{2}
\end{gathered}
$$

Where: $\mathrm{y}=$ hardness $(\mathrm{g}), \mathrm{x}_{1}=\mathrm{xanthan}$ content and $\mathrm{x}_{2}$ $=$ methylcellulose content.

The validity of the model for the hardness was checked by analysis of variance (ANOVA) (Tables 6 and 7). The differences between the experimental values and values predicted by the model (Table 8) were $10.10 \%$ at maximum values, the model obtained has an $\mathrm{R}^{2}$ value of 0.8856 and the calculated $\mathrm{F}$ was 4.15 times higher than the tabulated F. Thus, the model was predictive and is useful to estimate hardness depending on the dosages of xanthan gum and methylcellulose.

Table 6. Regression coefficients of the $2^{2}$ full rotational central composite design.

\begin{tabular}{cccccc}
\hline $\begin{array}{c}\text { Dependent } \\
\text { variable }\end{array}$ & Independent variable & $\begin{array}{c}\text { Regression } \\
\text { coefficients }\end{array}$ & Standard error & Value t & Value $\mathrm{p}$ \\
\hline \multirow{5}{*}{ Hardness } & Mean/Interaction & 838.1912 & 39.01421 & 21.48425 & 0.000004 \\
& (1) Xanthan gum (L) & 53.7484 & 23.92713 & 2.24634 & 0.074619 \\
& (2) Methylcellulose (L) & 125.7668 & 28.55129 & 4.40494 & 0.006990 \\
& Xanthan gum (Q) & 28.2074 & 23.92713 & 1.17889 & 0.291482 \\
& Methylcellulose(Q) & 175.6084 & 28.55129 & 6.15063 & 0.001652 \\
& 1L by 2L & -11.0875 & 33.78770 & -0.32815 & 0.756093 \\
\hline \multirow{5}{*}{ Score } & Mean/Interaction & 78.3933 & 0.810563 & 96.71469 & 0.000000 \\
& (1) Xanthan gum (L) & -3.6000 & 0.497113 & -7.24192 & 0.000784 \\
& (2) Methylcellulose (L) & 0.0529 & 0.593185 & 0.08928 & 0.932328 \\
& Xanthan gum (Q) & -4.7284 & 0.497113 & -9.51189 & 0.000217 \\
& Methylcellulose(Q) & 0.8074 & 0.593185 & 1.36121 & 0.231582 \\
& 1L by 2L & 1.4175 & 0.701977 & 2.01930 & 0.099459 \\
\hline
\end{tabular}

$\mathrm{L}=$ linear coefficient; $\mathrm{Q}=$ quadratic coefficient.

Table 7. Analysis of variance full $2^{2}$ rotational central composite design.

\begin{tabular}{ccccccccc}
\hline $\begin{array}{c}\text { Dependent } \\
\text { variable }\end{array}$ & $\begin{array}{c}\text { Source of } \\
\text { variation }\end{array}$ & $\begin{array}{c}\text { Quadratic } \\
\text { sum }\end{array}$ & $\begin{array}{c}\text { Degrees } \\
\text { freedom }\end{array}$ & $\begin{array}{c}\text { Quadratic } \\
\text { mean }\end{array}$ & $\mathrm{F}_{\text {calc }}$ & $\mathrm{F}_{\text {tab }}$ & $\mathrm{F}_{\text {calc }} / \mathrm{F}_{\text {tab }}$ & $\mathrm{R}^{2}$ \\
\hline \multirow{3}{*}{ Hardness } & Regression & 229858.32 & 3 & 76619.44 & 18.07 & 4.35 & 4.15 & 0.8856 \\
& Residue & 29670.21 & 7 & 4238.60 & & & & \\
& Total & 259528.53 & 10 & & & & & \\
\hline \multirow{2}{*}{ Score } & Regression & 289.74 & 3 & 96.58 & 49.30 & 4.35 & 11.33 & 0.9548 \\
& Residue & 13.71 & 7 & 1.95 & & & & \\
& Total & 303.45 & 10 & & & & & \\
\hline
\end{tabular}

$\mathrm{F}_{\text {calc }}=$ calculated $\mathrm{F} ; \mathrm{F}_{\mathrm{tab}}=$ tabulated $\mathrm{F} ; \mathrm{R}^{2}=$ coefficient of determination. 
Table 8. Comparison between the experimental values and the values predicted by the model for score and hardness of rice flour based gluten-free cakes.

\begin{tabular}{ccccccccc}
\hline & \multirow{2}{*}{$\begin{array}{c}\text { Xanthan } \\
\text { Essay }\end{array}$} & $\begin{array}{c}\text { Methylcellulose } \\
\text { (level) }\end{array}$ & EXP (g) & PRED (g) & $\begin{array}{c}\text { Deviation } \\
(\%)\end{array}$ & EXP & PRED & $\begin{array}{c}\text { Deviation } \\
(\%)\end{array}$ \\
\hline 1 & -1 & -1 & 1088.58 & 1085.82 & 0.25 & 90.00 & 88.75 & 1.39 \\
2 & 1 & -1 & 1147.71 & 1193.31 & -3.97 & 80.33 & 78.71 & 2.02 \\
3 & -1 & 1 & 1207.76 & 1085.82 & 10.10 & 77.00 & 76.45 & 0.71 \\
4 & 1 & 1 & 1222.54 & 1193.31 & 2.39 & 73.00 & 72.09 & 1.25 \\
5 & -1.41 & 0 & 935.17 & 1012.44 & -8.26 & 83.00 & 84.08 & -1.30 \\
6 & 1.41 & 0 & 1186.80 & 1164.01 & 1.92 & 72.33 & 73.92 & -2.20 \\
7 & 0 & -1.41 & 1149.09 & 1187.32 & -3.33 & 85.33 & 85.67 & -0.39 \\
8 & 0 & 1.41 & 1171.06 & 1187.32 & -1.39 & 73.00 & 72.33 & 0.92 \\
9 & 0 & 0 & 827.33 & 838.19 & -1.31 & 77.00 & 79.00 & -2.60 \\
10 & 0 & 0 & 802.36 & 838.19 & -4.47 & 78.66 & 79.00 & -0.43 \\
11 & 0 & 0 & 885.53 & 838.19 & 5.35 & 79.34 & 79.00 & 0.43 \\
\hline
\end{tabular}

EXP: value obtained experimentally; PRED: value predicted by the model using the coded variables; Deviation $(\%)=((\mathrm{EXP}-$ PRED)/EXP)x100.

Figure 1 shows the response surface of the hardness variation of the cakes as a function of the concentrations of xanthan gum and methylcellulose. It was observed that the best results (lowest value) of hardness were obtained at the central points of the design ( $0.4 \%$ xanthan gum and $2 \%$ methylcellulose), characterizing an optimization in the development of gluten-free cakes with the addition of xanthan gum and methylcellulose for the ideal hardness. Starting from the central point, the hardness value increases as the concentration of variables increases or decreases.

Hydrocolloids, also called gums, are long chain polymers of high molecular weight that are soluble in water and capable of increasing the viscosity of the system. They also help in the structure and, in some cases, form gels (GHARIBZAHEDI et al., 2012). The viscosity of the dough is a controlling factor in the final volume of the cake due to its effects on development and movement of the bubbles. Viscosity assists in the incorporation of air bubbles and protects bubbles rising to the surface, which provides greater stability for the cake and results in more volume and softness (NEITZEL, 2006). Therefore, the addition of the hydrocolloids methylcellulose and xanthan had a positive effect on the hardness of the cakes by increasing viscosity, which provided a greater retention of the gas formed during fermentation and thus lowered hardness. When high levels of hydrocolloids were added, viscosity became too high, making the cakes the hardest.

It is observed in Table 5 that the score values of the cakes ranged from 72.33 to 90 . These results were similar to those reported by Zavareze et al. (2010), where the sum of the score obtained was between 74.8 and 88.8 for wheat flour cakes added with whey and whose standard cake presented a total score of 83.8. Considering that the elaborated cakes do not contain gluten, it is noted that the scores assigned were satisfactory, showing that they are of comparable quality to a standard wheat flour cake.

For the score values, it was possible to verify the significant effect $(p<0.10)$ of the variables, allowing establishment of a mathematical model under the conditions studied, according to equation (2): 
Figure 1. Hardness variation of the gluten free cakes containing rice flour as a function of concentration of xanthan gum and methylcellulose.

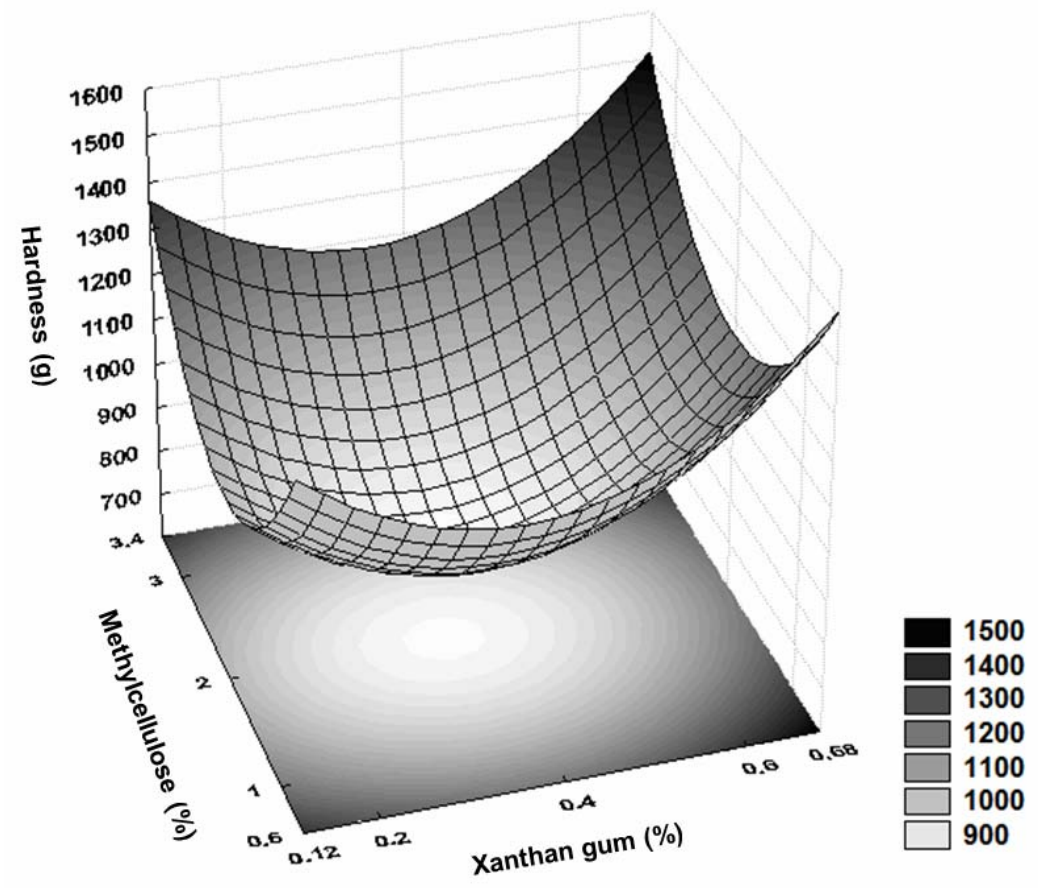

$\mathrm{y}=79.01727-3.60 \mathrm{x}_{1}-4.72848 \mathrm{x}_{2}+1.4175 \mathrm{x}_{1} \mathrm{x}_{2}$

Where: $\mathrm{y}=$ score values $(\mathrm{g}), \mathrm{x} 1=$ xanthan content and $\mathrm{x} 2=$ methylcellulose content.

The validity of the model for the score was verified by analysis of variance (ANOVA) (Tables 6 and 7). The differences between the experimental values and values predicted by the model (Table 8 ) were small (maximum 2.60), the model generated has an $\mathrm{R}^{2}$ value of 0.9548 and the calculated $\mathrm{F}$ was 11.33 times greater than the tabulated F. Thus, the model was predictive and is useful for estimating a score on the basis of dosages of xanthan gum and methylcellulose.

Figure 2 presents the response surface of the variation in the scores of cakes as a function of the concentrations of xanthan and methylcellulose. It was observed that the best score results (highest values) were obtained with lower concentrations of the variables $(0.12 \%$ xanthan and $0.6 \%$ methylcellulose). Among the quality attributes that were evaluated, those that showed the greatest change were uniformity and the alveolar size of the crumb structure. Both additives had a negative effect on the score value of the cakes, shown in the response surface of Figure 2, where it can be observed that the cakes with high concentrations of xanthan gum and methylcellulose presented lower scores. According to Rosell et al. (2001), the addition of xanthan provides a thickening of the walls around the gas cells formed in the dough. This thickening of the walls may have altered the structure of the core and the alveoli of the cakes that had the uneven crumb structure and slightly open or open alveoli, decreasing the total score. 
Figure 2. Score variation of the gluten free cakes containing rice flour as a function of concentration of xanthan gum and methylcellulose.

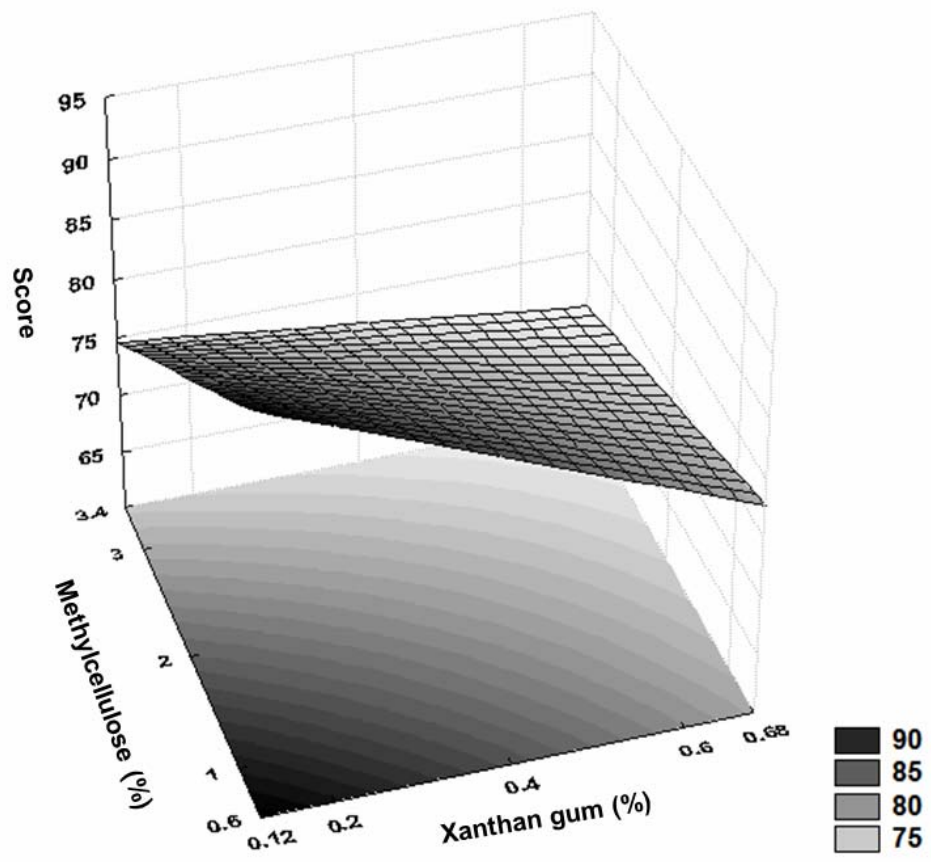

\section{Conclusion}

Theinfluence of xanthan gumand methylcellulose on the hardness and scores of gluten-free cakes was verified. Mathematical models that link the additives with these two technological features were obtained. No significant effect on specific volume was obtained.

The smallest value of the crumb hardness of the cakes was obtained when concentrations of $0.4 \%$ xanthan and $2 \%$ methylcellulose were added. Regarding the score, higher values were obtained with concentrations of $0.2 \%$ xanthan gum and $1 \%$ methylcellulose.

The addition of xanthan gum and methylcellulose enabled the development of a gluten-free cake with a softer crumb that presents technological quality attributes similar to that of a wheat flour cake.

\section{References}

AMERICAN ASSOCIATION OF CEREAL CHEMISTS - AACC. Approved Methods of the AACC. $10^{\text {th }}$ ed. St. Paul: American Association of Cereal Chemists, MN, 2000.

ARENDT, E. K.; O'BRIEN, C. M.; SCHOBER, T.; GORMLEY, T. R.; GALLAGHER, E. Development of gluten-free cereal products. Farm and Food Research, Dublin, v. 12, n. 2, p. 21-27, 2002.

ASH, M.; ASH, I. Handbook of food additives. Aldershot: Glower Publisher, 1995. 1025 p.

BORGES, J. T. S.; PIROZI, M. R.; LUCIA, S. M. D.; PEREIRA, P. C.; MORAES, A. R. F.; CASTRO, V. C. Utilização de farinha mista de aveia e trigo na elaboração de bolos. B.CEPPA, Curitiba, v. 24, n. 1, p. 145-162, jan./ jun. 2006.

BOX, G. E. P.; DRAPER, N. R. Empirical modelbuilding and response surface. New York: Wiley, 1987. $669 \mathrm{p}$. 
COLLAR, C.; ANDREU, P.; MARTINEZ, J. C.; ARMERO, E. Optimization of hydrocolloid addition to improve wheat bread dough functionality: a response surface methodology study. Food Hydrocolloids, Oxford, v. 13, n. 6, p. 467-475, 1999.

FIGUEIRA, F. S. Produção de pão sem glúten enriquecido com Spirulina platensis. 2010. Dissertação (Mestrado em Engenharia e Ciência de Alimentos) Universidade Federal do Rio Grande, Rio Grande.

FCC: NATIONAL ACADEMY OF SCIENCES. FOOD CHEMICALS CODEX - FCC. $4^{\text {th }}$ ed. Washington DC: National Academy Press, 1996.

GHARIBZAHEDI, S. M. T.; MOUSAV, I. S. M.; HAMEDI, M.; KHODAIYAN, F.; RAZAVI, S. H. Development of an optimal formulation for oxidative stability of walnut-beverage emulsions based on gum arabic and xanthan gum using response surface methodology. Carbohydrate Polymers, London, v. 87, n. 2, p. 1611-1619, 2012.

GORGÔNIO, C. M. S.; PUMAR, M.; MOTHE, C. G. Macrocospic and physiochemical characterization of a sugarless and gluten-free cake enriched with fibers made from pumpkin seed (Cucurbita maxima, L.) flour and cornstarch. Ciência e Tecnologia de Alimentos, Campinas, v. 31, n. 1, p. 109-118, jan./mar. 2011.

GUARDA, A.; ROSELL, C. M.; BENEDITO, C.; GALOTTO, M. J. Different hydrocolloids as bread improvers and antistaling agents. Food Hydrocolloids, Oxford, v. 18, n. 2, p. 241-247, 2004.

LAZARIDOU, A.; DUTA, D.; PAPAGEORGIOU, M.; BELE, N.; BILIADERIS, G. G. Effects of hydrocolloids on dough rheology and bread quality parameters in gluten-free formulations. Journal of Food Engineering, Amsterdan, v. 79, n. 3, p. 1033-1047, 2007.

MOREIRA, M. R. Elaboração de pré-mistura para pão sem glúten para celíacos. 2007. Dissertação (Mestrado em Ciência e Tecnologia dos Alimentos) - Universidade Federal de Santa Maria, Santa Maria.

MOSCATTO, J. A.; PRUDÊNCIO-FERREIRA, S. H.; HAULY, M. C. O. Farinha de yacon e inulina como ingredientes na formulação de bolo de chocolate. Ciência e Tecnologia de Alimentos, Campinas, v. 24, n. 4, p. 634640, 2004.

NEITZEL, L. H. Influência da formulação no congelamento de massas de bolo e na qualidade do produto final. 2006. Dissertação (Mestrado em Ciência e Tecnologia Agroindustrial) - Universidade Federal de Pelotas, Pelotas.
NEUMANN, H.; BRUEMMER, J. M. Investigations with the production of gluten free bread and roll specialties. Getreide Mehl und Brot, Bochum, v. 51, n. 1, p. 50-55, 1997.

NISHITA, K. D.; ROBERTS, R. L.; BEAN, M. M. Development of yeast-leveaned rice-bread formula. Cereal Chemistry, Manhattan, v. 53, n. 5, p. 626-635, 1976.

ONYANGO, C.; UNBEHEND, G.; LINDHAUER, M. G. Effect of cellulose-derivatives and emulsifiers on creep-recovery and crumb properties of gluten-free bread prepared from sorghum and gelatinized cassava starch. Food Research International, Barking, v. 42, n. 8, p. 949955, 2009.

PAVANELLI, A. P.; CICHELlO, M. S.; PALMA, E. J. Emulsificantes como agentes de aeração em bolos. São Paulo: Oxiteno, 2000. Disponível em: <http://www. oxiteno.com.br>. Acesso em: 1 maio 2013.

PIZZINATO, A.; CAMPAGNOLLI, D. M. F. Avaliação tecnológica de produtos derivados da farinha de trigo (pão, macarrão, biscoitos). Campinas: Boletim ITAL, 1993. $54 \mathrm{p}$.

PREICHARDT, L. D.; VENDRUSCOLO, C. T.; GULARTE, M. A.; MOREIRA, A. S. Efeito da goma xantana nas características sensoriais de bolos sem glúten. Revista Brasileira de Tecnologia Agroindustrial, Ponta Grossa, v.3, n.1, p. 70-76, 2009.

RODRIGO, L. Celiac disease. World Journal of Gastroenterology, Beijing, v. 12, n. 41, p. 6585-6593, 2006.

RONDA, F.; ROOS, Y. H. Staling of fresh and frozen gluten-free bread. Journal of Cereal Science, London, v.53, n. 3, p. 340-346, 2011.

ROSELL, C. M.; COLLAR, C. Rice based products. In: HUI, Y. H. (Ed.). Handbook of food products manufacturing. Ames: Blackwell Publishing, 2007. p. 123-133.

ROSELL, C. M.; HAROS, M.; ESCRIVA, C.; BENEDITO de BARBER, C. Experimental approach to optimize the use of $\alpha$-amylases in bread making. Journal of Agricultural and Food Chemistry, Washington, v. 49, n. 6, p. 2973-2977, 2001.

STORCK, C. R.; PEREIRA, J. M.; PEREIRA, G. W.; RODRIGUES, A. O.; GULARTE, M. A.; DIAS, A. R. G. Características tecnológicas de pães elaborados com farinha de arroz e transglutaminase. Brazilian Journal of Food Technology, Campinas, Edição Especial - II Simpósio de Segurança Alimentar, p. 71-77, 2009. 
TURABI, E.; SUMNU, G.; SAHIN, S. Rheological properties and quality of rice cakes formulated with different gums and an emulsifier blend. Food Hidrocolloids, Oxford, v. 22, n. 2, p. 305-312, 2008.

XUE, J.; NGADI, M. Effects of methylcellulose, xanthan gum and carboxymethylcellulose on thermal properties of batter systems formulated with different flour combinations. Food Hydrocolloids, Oxford, v. 23, n. 2, p. 286-295, 2009.
ZAVAREZE, E. R.; MORAES, K. S.; SALASMELLADO, M. M. Qualidade tecnológica e sensorial de bolos elaborados com soro de leite. Ciência e Tecnologia de Alimentos, Campinas, v. 30, n. 1, p. 100-105, jan./mar. 2010. 